\title{
INSTRUMENTS AND METHODS \\ SNOW DENSITY PROFILING BY NUCLEAR MEANS
}

\author{
By RoBert D. Leighty
}

(U.S. Army Cold Regions Research and Engineering Laboratory, Hanover, New Hampshire,
U.S.A.)

Abstract. During the period 8-19 May 1963 a preliminary field investigation was conducted in Greenland to determine the feasibility of using a nuclear technique to determine snow and ice density profiles. A standard nuclear soil-moisture depth probe was used with two modes of processing and recording the nuclear pulses. Example data are compared with snow densities obtained by the standard weighing technique. The nuclear method was found to be feasible; however, deficiencies related to poor resolution render the probe unusable for detailed profiling of snow stratigraphy in its present form, but expected progress in nucleonics should enable improved resolution and accuracy to be achieved by improvement of nuclear detectors.

RÉsumé. Détermination de profils de densité par des moyens nucléaires. Pendant la période du 8 au ig mai ig63, une investigation préliminaire a été conduite au Groenland pour déterminer l'utilisation d'une technique nucléaire à l'obtention de profils de densité dans la neige et la glace. Une sonde standard nucléaire pour la détermination de l'humidité du sol a été utilisée avec deux modes d'obtenir et d'enrégistrer les pulsations nucléaires. Les données obtenues sont comparées avec les densités de neige obtenues par la méthode standard de la pesée.

La méthode nucléaire semble être utilisable; cependant, des déficiences liées à de faibles résolutions rendent la sonde inutilisable pour obtenir un profil détaillé de la stratigraphie de la neige dans sa présente forme, mais une amélioration attendue en technique nucléonique doit permettre d'améliorer la résolution et la précision.

Zusammenfassung. Bestimmung von Schneedichteprofilen mit nuklearen Mitteln. In der Zeit vom 8.-19. Mai 1963 wurde in Grönland eine erste Felduntersuchung mit dem Ziel vorgenommen, die Brauchbarkeit einer nuklearen Methode zur Bestimmung von Dichteprofilen in Schnee und Eis festzustellen. Verwendet wurde die gebräuchliche nukleare Tiefensonde für Bodenfeuchtigkeit mit zwei Arten der Verarbeitung und Aufzeichnung der nuklearen Impulse. Die Probewerte wurden mit Schneedichten verglichen, die durch die gewöhnliche Wiege-Methode gewonnen worden waren.

Die nukleare Methode erwies sich als anwendbar. Doch ist die Sonde in ihrer derzeitigen Form durch Mängel, die in der geringen Auflösung liegen, ungeeignet für eine detaillierte Bestimmung der Stratigraphie in den Schneeprofilen. Mit dem Fortschritt der Kerntechnik kann eine höhere Auflösung und Genauigkeit durch Verbesserung der nuklearen Anzeigegeräte erwartet werden.

\section{INTRODUCTION}

The use of radioisotopes for measurement of snow density is not new. Gerdel and others (1950) report on a radiotelemetering snow gage used successfully to measure up to 55 waterequivalent inches $(\mathrm{r} \cdot 4 \mathrm{~m}$.) of a snow-pack using the principle of absorption by water of gamma emissions from a cobalt 6o source. Bader and others (I 95 I, p. I $5^{-1} 8$ and 4 I) discuss an X-ray density scanning technique and instrument which determined the density of snow by measuring the attenuation of a transmitted beam of X-rays in accordance with Lambert's law. In general these transmission techniques require a collimated source-detector combination, separated a known distance. For profiling snow densities this also requires simultaneous lowering of a source and detector in separate holes.

Geophysical exploration in the petroleum industry was responsible for the initial development of present-day radioactive well-logging techniques. Use of neutrons for drill-hole surveying was first suggested and tested by Pontecorvo (r94I). His technique utilized a detector in close proximity to the source in a single probe and as such was the first use of the reflectance or scattering technique.

First use of nuclear probes to investigate soils for engineering purposes was reported by Belcher and others (1950). Their equipment consisted of two probes. One probe, which measured the moisture or hydrogen content of the soil, had a neutron source with foil or Geiger 
tube detectors, and the other probe, which measured soil density, used a gamma-ray source and a Geiger tube detector.

Leighty and Frankenstein (unpublished) made limited tests on snow and ice with a surface soil-moisture gage and found the neutron count rate to be a linear function of density over the sampled density range of 0.3 i to $0.9^{2} \mathrm{~g} . / \mathrm{cm} .^{3}$. Gay (1962); Anderson and others (1962, 1963) and Anderson (1963) report on the use of a depth moisture probe and a depth density probe for investigating snow-pack profiles within the density range of $0 . \mathrm{I}_{\mathrm{I}}$ to $0.5^{2} \mathrm{~g} . / \mathrm{cm} .^{3}$ in the Rocky Mountains.

Early in 1962 United States Army Cold Regions Research and Engineering Laboratory research funds to investigate nuclear techniques for measurements of snow density were made available. A rapid method of direct determination of snow density by logging the count rate of a neutron probe lowered in a hole at a continuous rate was envisioned. A commercial neutron probe satisfied the requirements for a fixed geometric relationship between source and counter to ensure reproducible measurements, since the method consists in measuring the density of scattered neutrons at a given distance from the source. Prior to the field work it was realized that such a commercially available soil-moisture depth probe might not have the desirable characteristics for optimum determination of snow density profiles, but experience gained from its use would point to later modifications to improve the technique if justified. This paper discusses the preliminary field investigations conducted in Greenland during the period 8-ig May i 963.

\section{Equipment and Procedure}

The basic project equipment for nuclear measurement consisted of the nuclear probe, a scaler, a rate-meter and a chart recorder. The standard SIPRE snow observation kit, SIPRE 3 -in. $\left(7 \cdot 6 \mathrm{~cm}\right.$.) coring auger kit and the $1 \frac{1}{2}$ in. $(3 \cdot 8 \mathrm{~cm}$.) auger from the SIPRE ice thickness kit were used to obtain gravimetric snow density samples and provide holes into which the nuclear probe was lowered. The probe, Nuclear Chicago Model P-I9, Subsurface Soil Moisture Probe, had a 4.5 millicurie radium-beryllium fast neutron source and one boron floride thermal neutron detector tube with a sensitive length of $5.5 \mathrm{in}$. (14 cm.). The probe had an external diameter of $\mathrm{I} \frac{1}{2}$ in. $\left(3.8 \mathrm{~cm}\right.$.) with a $5^{\circ} \mathrm{ft}$. ( $\mathrm{I} 5 \mathrm{~m}$.) connecting cable graduated in 2 in. $(5.08 \mathrm{~cm}$.) increments.

Two modes of obtaining the nuclear data were used. Mode I, the probe-rate-meterchart-recorder combination, produced a continuous chart record of the variation of the nuclear count rate with depth: Mode 2, the probe-scaler combination, produced a visual indication of the nuclear counts for a selected time duration when the probe was at a stationary position in the hole; repeating this count procedure at different selected depths allowed construction of a curve similar to that obtained with the rate-meter.

The general procedure for data collection consisted of (I) coring a vertical hole with the $I_{2} \frac{1}{2}$ in. $(3.8 \mathrm{~cm}$.) auger, (2) obtaining the profile of nuclear count rate versus depth using both Modes $\mathrm{I}$ and 2, and (3) determining the density profile of the snow by standard gravimetric sampling procedures with the $500 \mathrm{~cm} .{ }^{3}\left(30 \cdot 5\right.$ in. $\left.{ }^{3}\right)$ sample tubes from the snow observation kit and/or sections of the 3 in. $(7 \cdot 6 \mathrm{~cm}$.) vertical core obtained with the coring auger.

\section{REsults}

Because the nuclear determination of snow density is an indirect method, an initial correlation with the field sample density is necessary. Figure I shows the results of the correlation between scaler count ratio and the snow sample density; count ratio (which varies from $\mathrm{o}$ to $\mathrm{I} \cdot \mathrm{o}$ for any neutron probe) is the ratio of scaler count rate in snow to scaler count rate in 
water. The data in Figure I represent snow sample densities from 0.32 to about 0.70 and lake-ice densities of 0.87 to $0.9 \mathrm{I} \mathrm{g} . / \mathrm{cm} .{ }^{3}$ The maximum range in density for any given count ratio was from 0.40 to 0.70 , a difference of $0.30 \mathrm{~g} . / \mathrm{cm} .^{3}$ This variation is unacceptable for

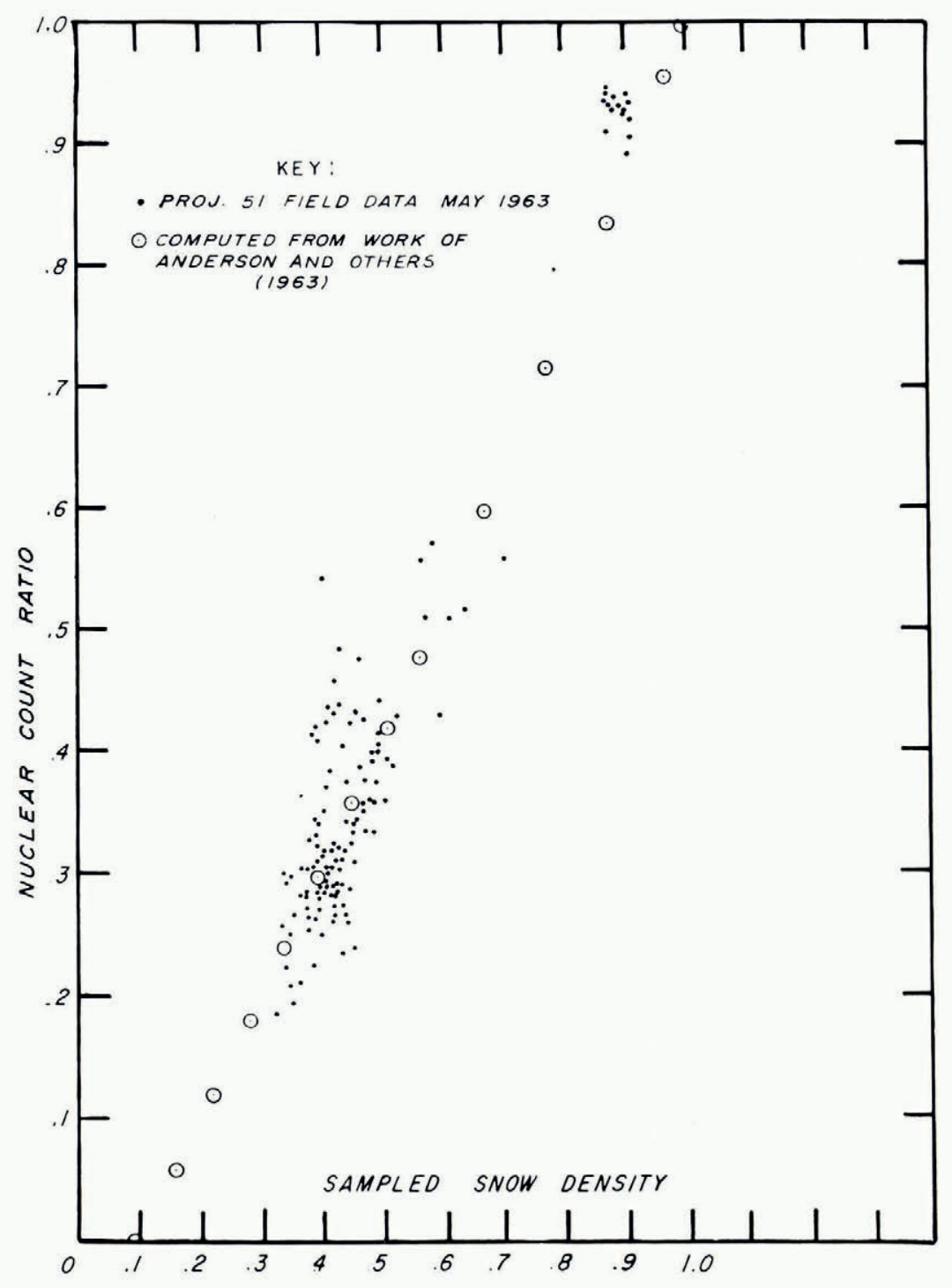

Fig. I. Scaler count ratio plotted against sampled snow density in $\mathrm{g} . / \mathrm{cm} .^{3}$

profiling snow stratigraphy; however, the major portion of the variation may be related to the inexperience of the snow samplers and to the difference between the effective sample volume in the nuclear method compared with that in the standard gravimetric method. Errors attributable to poor technique for obtaining and weighing samples and failure to sample a real density variation could contribute greatly to the discrepancies. The density at 
any given depth below the surface was seen to vary, and the density profile at the site of the nuclear measurements could have been different from that at the site of the standard density measurements. The largest source of error, however, is attributed to sample volumes. In snow of density $0.40 \mathrm{~g} . / \mathrm{cm} .^{3}$ it is estimated that the effective diameter of the neutron cloud around the source is $4 \mathrm{I} \cdot 5 \mathrm{~cm}$. ( $16 \cdot 3$ in.) a spherical volume of about $37,000 \mathrm{~cm} . .^{3}\left(2,300 \mathrm{in}^{3}\right)$. This is about 74 times as great as the $500 \mathrm{~cm} .^{3}\left(30 \cdot 5\right.$ in. $\left.{ }^{3}\right)$ from the density sample tube and more than 100 times as great as a 3 -in. $(7 \cdot 6 \mathrm{~cm}$.) section of snow from the 3 -in. $(7 \cdot 6 \mathrm{~cm}$.) coring auger. A variation in density of snow within the neutron sphere will affect the count rate and may not be detected by the density sampling of a novice.

Anderson and others ( 1963 ) present a formula for a regression curve for count rate and snow density with the P-r 9 probe. The computed results, divided by their water count, are presented by the circled points in Figure $\mathrm{I}$. There is reasonable agreement between the project data and a line representing the mean of their correlation curve. It is thought that discrepancies should exist because of the difference in snow conditions of the Rocky Mountains and the Greenland Ice Sheet. The heavy snowfalls of the mountains, which usually measure feet (metres), tend to develop thick strata of uniform densities, while in Greenland snowfall is measured in inches (centimetres) and large density differences can be found in closely spaced strata of small thicknesses.

Field data obtained at the lower portion of the TUTO Ramp, on the ice sheet about one mile ( $\mathrm{I} \cdot 6 \mathrm{~km}$.) from the ice-land boundary, are shown in Figure 2. Here $4 \mathrm{ft} .4$ in. $(\mathrm{I} \cdot 32 \mathrm{~m}$.) of winter snow covered the glacial ice, so that an abrupt density difference existed at the snow-ice interface. As seen from this illustration, the sampled snow density ranged from 0.320 to $0.492 \mathrm{~g}$. $/ \mathrm{cm}^{3}{ }^{3}$, while the sampled ice densities ranged from 0.863 to $0.901 \mathrm{~g} . / \mathrm{cm} .{ }^{3}$. Not shown in this illustration were two thin ice lenses, each about $\frac{1}{32} \mathrm{in}$. $(0 \cdot 8 \mathrm{~mm}$.) in thickness, $31 \frac{1}{4}$ in. $(79 \cdot 5 \mathrm{~cm}$.) and 40 in. (IOI $5 \mathrm{~cm}$.) below the surface. Two-minute scaler counts, beginning ro in. $(25.4 \mathrm{~cm}$.) below the surface and spaced every $6 \mathrm{in}$. $(15.2 \mathrm{~cm}$.) thereafter, are shown to approximate the variations in sample densities, except in the regions immediately below the snow-ice interface. The scaler measurement at $4 \mathrm{ft} .3$ in. does not show the expected increase in count rate when the source was only one inch $\left(2.54 \mathrm{~cm}\right.$.) above the ice and $\mathrm{I} \frac{1}{2}$ in. $(3.8 \mathrm{~cm}$.) of the detector tube was beneath the snow-ice interface. The diameters of the neutron cloud around the source in snow of $0.40 \mathrm{~g} . / \mathrm{cm} .{ }^{3}$ density and ice of $0.90 \mathrm{~g} . / \mathrm{cm} .{ }^{3}$ density are approximately $\mathrm{I}_{6}$ and $\mathrm{I} 2 \mathrm{in}$. (4I and $30 \mathrm{~cm}$.) respectively and since the scaler count rate at $5 \mathrm{ft} .3$ in. seems to result entirely from the ice count, it is assumed that the snow-ice interface in the sample fit and in the probe hole were at different depths. This could be possible on the TUTO Ramp. A vertical difference of 6 in. in $20 \mathrm{ft}$. or so from probe hole is not an unreasonable variation for the ice surface, which is exposed to melt-water run-off each summer. The rate-meter curve obtained with a time constant of $2 \mathrm{sec}$. intersects most of the scaler points in Figure 2. Rate-meter curves at Io sec. and $20 \mathrm{sec}$. time constants are smoother, follow only the general trend of the scaler points in the snow and ice, and show a gradual change in count rate for the probe travel up-hole through the snow-ice interface.

With an assumed correlation curve of count rate versus snow density and curves for statistical deviations of neutron count rates, curves were constructed for statistical deviations in snow density at different probability levels for the scaler and rate-meter data. These curves, while not entirely correct, demonstrate that the nuclear technique has possibilities of producing the statistical accuracy for determining snow density profiles.

The reproducibility of the rate-meter curves was well within the theoretical statistical deviations at the 95 per cent probability level and this denotes that any deflection of the curves having duplication could be attributed to differences in snow density profile. As expected, when the $\mathrm{I} \frac{1}{2}$ in. $(3 \cdot 8 \mathrm{~cm}$.) probe was suspended in the center of a 5 in. $(12 \cdot 7 \mathrm{~cm}$.) hole, the annulus of air surrounding the probe reduced the number of neutrons scattered back to the detector. 


\section{SUMMARY}

A direct record of snow density versus depth is a distinct possibility for the near future when the resolution of the profile stratigraphy can be improved by perfecting the sourcedetector combination. The rapidly advancing state of the art of nucleonics will provide increased resolution as well as increased accuracy.

$M S$. received 21 April 1965

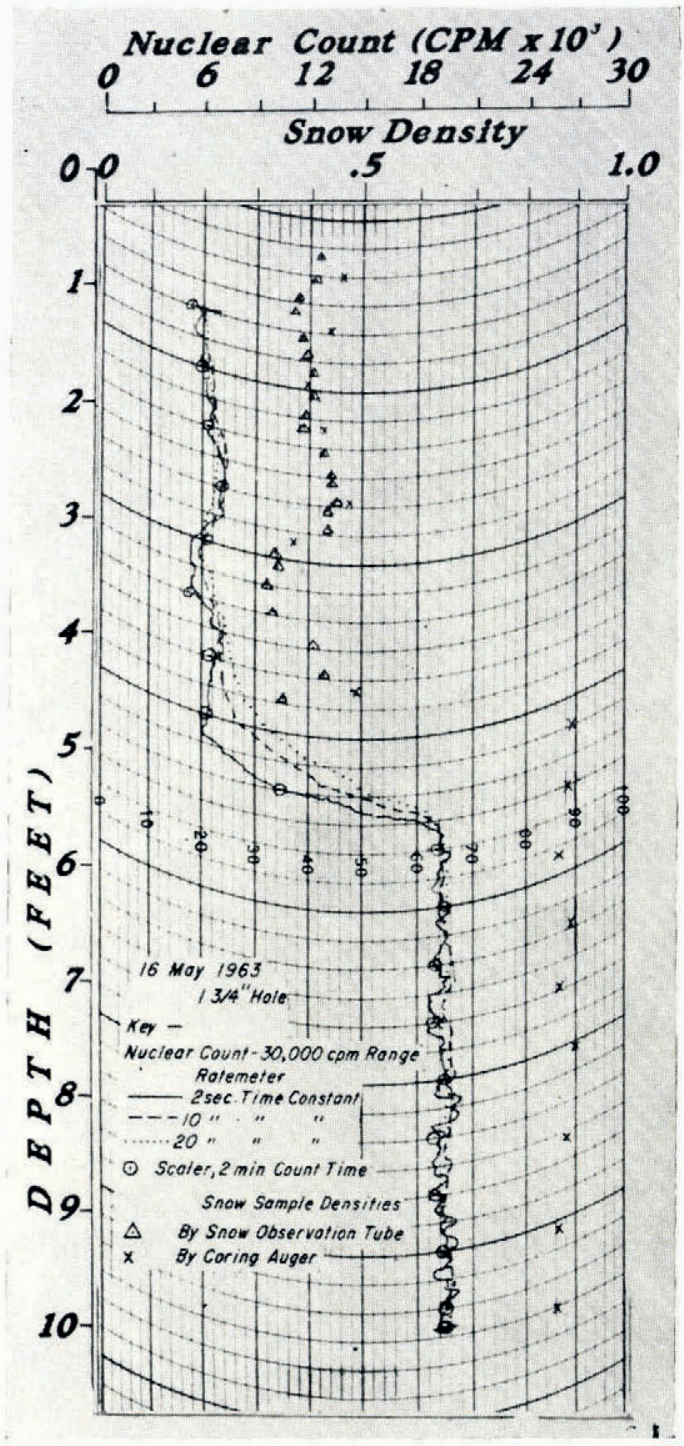

Fig. 2. Field data obtained on the lower portion of TUTO Ramp, Thule, Greenland, ${ }_{1} 6$ May ${ }_{19} 6_{3}$, show the snow density profiles and nuclear profiles obtained by the scaler and rate-meter modes. The rate-meter curves were obtained during up-hole travel of the probe 


\section{REFERENCES}

Anderson, H. W. 1963. Use of radioactive sources in measuring characteristics of snowpack. U.S. Forest Service. Pacific South-west Forest and Range Experiment Station. Note PSW-I I.

Anderson, H. W., and others. 1962, 1963. Gamma and neutron probes for measuring hydrologic characteristics of snow, by H. W. Anderson, P. M. McDonald and L. W. Gay. Transactions. American Geophysical Union, Vol. 43, No. 4, p. 450; Vol. 44, No. I, p. 48. [Abstracts.]

Bader, H., and others. 195I. Preliminary investigations of some physical properties of snow, by H. Bader, B. L. Hansen, J. H. Joseph and M. A. Snadgren. U.S. Snow, Ice and Permafrost Research Establishment. Report 7.

Belcher, D. J., and others. 1950. The measurement of soil moisture and density by neutron and gamma ray scattering, by D. J. Belcher, T. R. Cuykendall and H. S. Sack. U.S. Civil Aeronautics Administration. Technical Development Report 127.

Gay, L. W. 1962. Measuring snowpack profiles with radioactive sources. Proceedings of the Western Snow Conference, 3oth annual meeting, 1962, p. 14-19.

Gerdel, R. N., and others. 1950. The use of radioisotopes for measurement of the water equivalent of a snow-pack, by R. N. Gerdel, B. L. Hansen and W. C. Cassidy. Transactions. American Geophysical Union, Vol. 31, No. 3,

p. 449-53.
Leighty, R. D., and Frankenstein, G. E. Unpublished. Use of a portable nuclear method for determination of snow and ice density. U.S. Snow, Ice and Permafrost Research Establishment. Technical Note. [Written 1961.]

Pontecorvo, B. I94I. Neutron well logging; a new geological method based upon nuclear physics. Oil and Gas Fournal (Tulsa, Okla.), Vol. 40, No. 18, p. 32-33. 